\title{
Evolution and Termination of Lakes in Jordan and Their Relevance to Human Migration from Africa to Asia and Europe
}

\author{
Elias Salameh"1, Klaus Bandel'2, Ikhlas Alhejoj3 ${ }^{3}$, Ghaida Abdallat ${ }^{1}$ \\ ${ }^{1}$ Center for Strategic Studies, University of Jordan, Amman, Jordan \\ ${ }^{2}$ University of Hamburg, Hamburg, Germany \\ ${ }^{3}$ Department of Geology, University of Jordan, Amman, Jordan \\ Email: salameli@Ju.edu.jo,klausbandel@yahoo.com, ikhlas_alhejoj@yahoo.com, ghidaaabdallat@yahoo.com
}

How to cite this paper: Salameh, E., Bandel, K., Alhejoj, I. and Abdallat, G. (2018) Evolution and Termination of Lakes in Jordan and Their Relevance to Human Migration from Africa to Asia and Europe. Open Journal of Geology, 8, 1113-1132. https://doi.org/10.4236/ojg.2018.812068

Received: October 26, 2018

Accepted: November 25, 2018

Published: November 28, 2018

Copyright $\odot 2018$ by authors and Scientific Research Publishing Inc. This work is licensed under the Creative Commons Attribution International License (CC BY 4.0).

http://creativecommons.org/licenses/by/4.0/

\begin{abstract}
The hydrologic system in Jordan began its evolution with the regression of the Tethys during the Eocene and the rifting of Arabia from Africa. From that time onward Jordan lay on land. The rivers from Jordan and the Sirhan east of it flew into the Rift. On the Jordan land volcanism developed and was on and off active until sub-recent times. Flows of magma covered large areas in north and central Jordan. The uppermost hard layers of the deep valleys of the Yarmouk and the Mujib present evidence for their later erosion. The land to the east of the rift was low and in depressions lakes formed on the Jordan plateau, which began to rise less than half a Million years ago. Especially the Jafr and the Azraq Lakes developed a belt of green vegetation that attracted numerous animals which were hunted by early men. Tools for hunting and food preparation were produced from flint and assembled next to the former lake shores with time. The shape of these flint tools allows a coarse dating and documents the arrival of humans hundred thousand years ago and of modern men between 50,000 and 80,000 years ago. Great changes in the shape of the eastern Rift margin had occurred before Lake Lisan evolved and its rising water flooded the mouths of canyons for example of Wadi Hasa, Wadi Mujib and Wadi Zerka Ma'in. On former gravel fans into Lake Lisan of the Tabaqat Fahl first agriculture still in Neolithic times evolved as well as in Amman where people from Ain Ghazal planted crops like barley and peas, beans, lentils and chickpeas and domesticated sheep, goats and pigs. The existence of the highland lakes seems to have been of utmost importance to human migrations from Africa. Such lakes provided water and food for those humans in the Arid area of Jordan.
\end{abstract}




\section{Keywords}

Hydrology, Epeirogenic, Taphrogenic, Uplifts, Volcanic Eruptions, Human Migration

\section{Introduction}

A number of Pleistocene lakes had existed in the plateau area of Jordan lying east of the Jordan Rift Valley (JRV) eastern shoulders and west of the escarpment separating Sirhan water shed (along the Northeastern to Saudi Arabian border line) from that of the JRV. Most of these lakes dried out during the last stages of the Pleistocene and beginning of the Holocene. The sediments of these lakes and their fossil contents have been studied by many authors [1]-[7]. Ancient human remains in the surroundings of these lakes were also studied by a number of authors [3] [8] [9].

The evolution of the hydrologic system after the start of the last Tethys regression during the Neogene and the formation and disappearance of these lakes are not well clarified until now. Reference has always been made to climatic changes which supposedly have led to the drying of the lakes. Head ward erosion of the eastern Jordan Rift Valley wadis has not been considered as the main mechanism behind the drying of the Plateau lakes. In this article it will be tried to reconstruct the hydrologic system and the accompanying formation of these lakes. In addition, the sediments and fossils deposited in these lakes are used to clarify the environmental conditions and types of water which governed the formation of sediments and life in these lakes. The importance of the presence of these lakes to human migrations from Africa through Jordan is also highlighted.

\section{Methodology}

In this study the evolution of the hydrological system after the start of the last regression of the Tethys during the Neogene is elaborated and its development until the recent geologic history followed. The used methodology is reconstruction of the paleo-hydrologic system and its evolution since the commencement of the last Tethys regression and the following rifting along the Jordan Valley based on sediments deposited in depressions and their contents of fossils. The development of the hydrologic regime is correlated to epeirogenic and taphrogenic tectonics, to volcanic eruptions and to mass wasting which started with the last regression of the Tethys during the Neogene. Types of lakes, ages, depositional environments and human artifacts are used to assist in clarifying the relevance of the evolution of the hydrologic system for human migrations from Africa through Jordan to Asia and Europe.

\section{Results and Findings}

Considering the shorelines of the Lower Cretaceous (Figure 1) as established by 


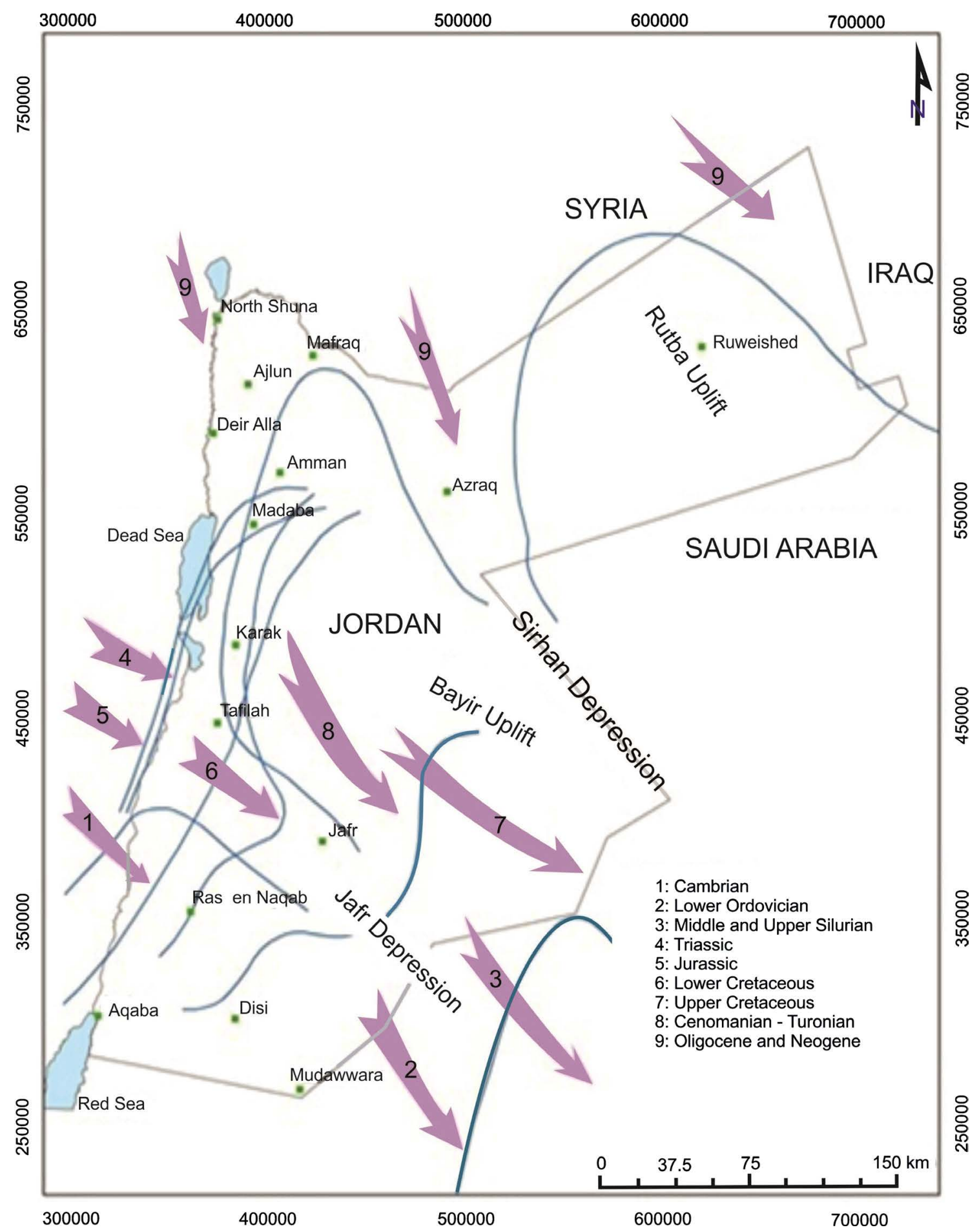

Figure 1. Transgressions over the area of Jordan since Cambrian time indicate that the drainage during late Neogene and Pleistocene times (Line 9) took place through Sirhan (Azraq) and Jafr depressions (Modified and redrawn after Bender, 1968).

[2] [5] and [10], it can be realized that in Jordan two geomorphological depressions, reflecting tectonics, controlled the geology of the area throughout its history at least since Lower Cretaceous time. These are the Jafr depression trending NW-SE with its center in Jafr and the Sirhan depression trending NW-SE with its 
center along that depression, forming the bottom of the Tethys during its regression. An uplifted area, also trending in $\pm \mathrm{NW}$-SE direction, has existed throughout, but at least, since Lower Cretaceous time. To the NE and SW of these depressions two uplifted areas existed, these are: Rutba uplift in the border area of Jordan with Iraq; to the NE of Sirhan depression and Ras en Naqb uplift in southwest Jordan; SW of Jafr depression both trending also NW-SE. During periods of known major regressions during Lower Cretaceous and Oligocene [2] (Figure 1), these depressions formed gulfs (estuaries) of the Tethys (Figure 2).

With the start of the last Tethys regression from the Levant area during the Neogene and as a result of epeirogenic movements Jordan's territories started to be drained through three main topographic depressions; namely wadi Sirhan in the northeast, Jafr in the middle and Disi in the south (Figure 2). Sirhan and Jafr depressions drained, at that time, towards \pm northwest, across what has developed to become the Jordan Rift Valley, into the retreating Tethys which later on evolved to become the Mediterranean Sea. Along Jafr and Sirhan depressions different sediments of Miocene and Pliocene ages composed of limestone, sandstone, siltstone and marls were deposited [2].

The Tethys regression can be traced with nummulite-limestone facies. But after its deposition in very shallow normal sea water, the Tethys obviously withdrew to the north of Jordan and there are no sediments that can be dated from last nummulites to Oligocene Mollusks and Foraminifera from the Tayba Formation near Azraq and especially the northern rim of the Jordan Rift to Abu Habil. Thus probably something like 10 million years during which the Tethys left Jordan for good.

The drainage of Disi area, in southwest Jordan, was oriented to the southwest to the Gulf of Aqaba and with the start of uplifts, due to taphrogenic movements, part of the runoff drained east-northeast either to Jafr or wadi Sirhan with an intermediate stage, during which local lakes in Disi and Mudawwara areas had formed [5] and [11].

With the start of rifting along the Jordan Rift Valley a new base level for surface and groundwater was established, namely the Jordan Rift Valley where surface and groundwater with their chemical and mechanical loads found their ultimate deposition sites.

The topographic slopes of whole Jordan, before the start of the taphrogenic uplift movements along what became the Jordan Rift Valley, were directed towards west-northwest. The formation of the Rift Valley accompanied by uplift movements of its eastern and western shoulders [1] and [2], must have resulted in the formation of three different types of base levels for the surface and groundwater of the area and its surroundings, namely; the depression along the newly subsiding Rift Valley floor, the Mediterranean to which the drainage of the western parts of the western shoulders of the rift drained and a series of north-south distributed local lakes in the Plateau area, to the east of the eastern shoulders of the Rift Valley such as Jafr, Hasa, Swaqa and Qatraneh to which water from the eastern shoulders of the Rift and from east Jordan along the 


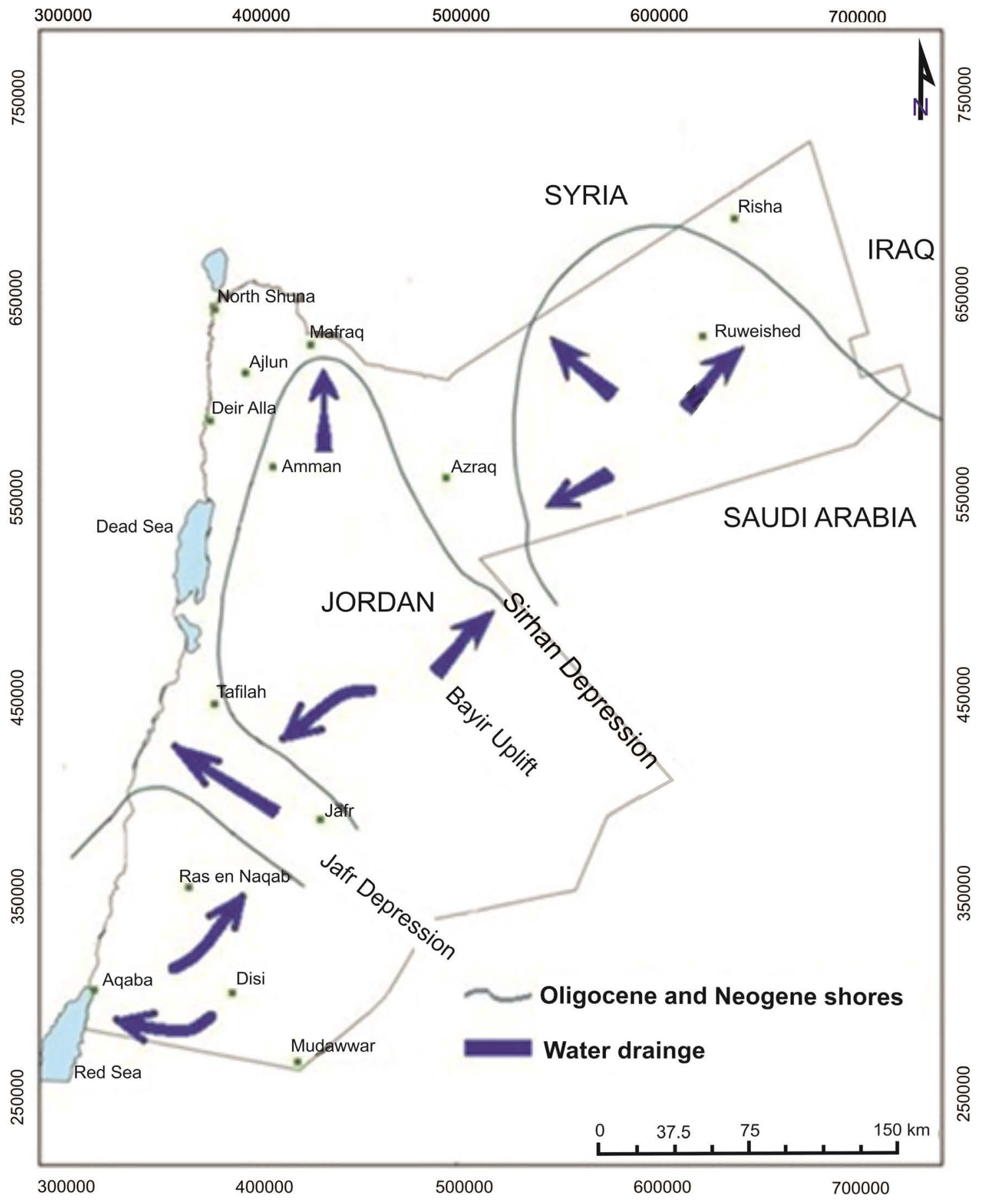

Figure 2. Surface water drainage in Jordan after the start of the last Tethys regression from the Levant from Oligocene time onward (based on Bender, 1968 and Bandel and Salameh, 2013).

pre-rift wadis drained (Figure 3).

During deposition of Tayba Formation, that is Late Oligocene to Early Miocene the sea had obviously flooded some parts of northern Jordan and the Jordan Dead Sea Rift begun to form, at the same time when Arabia began to rotate of Africa and the Red Sea Graben formed. The Sea flooded the northern part of the Rift, which has been sinking and had flanks with beaches between north of 


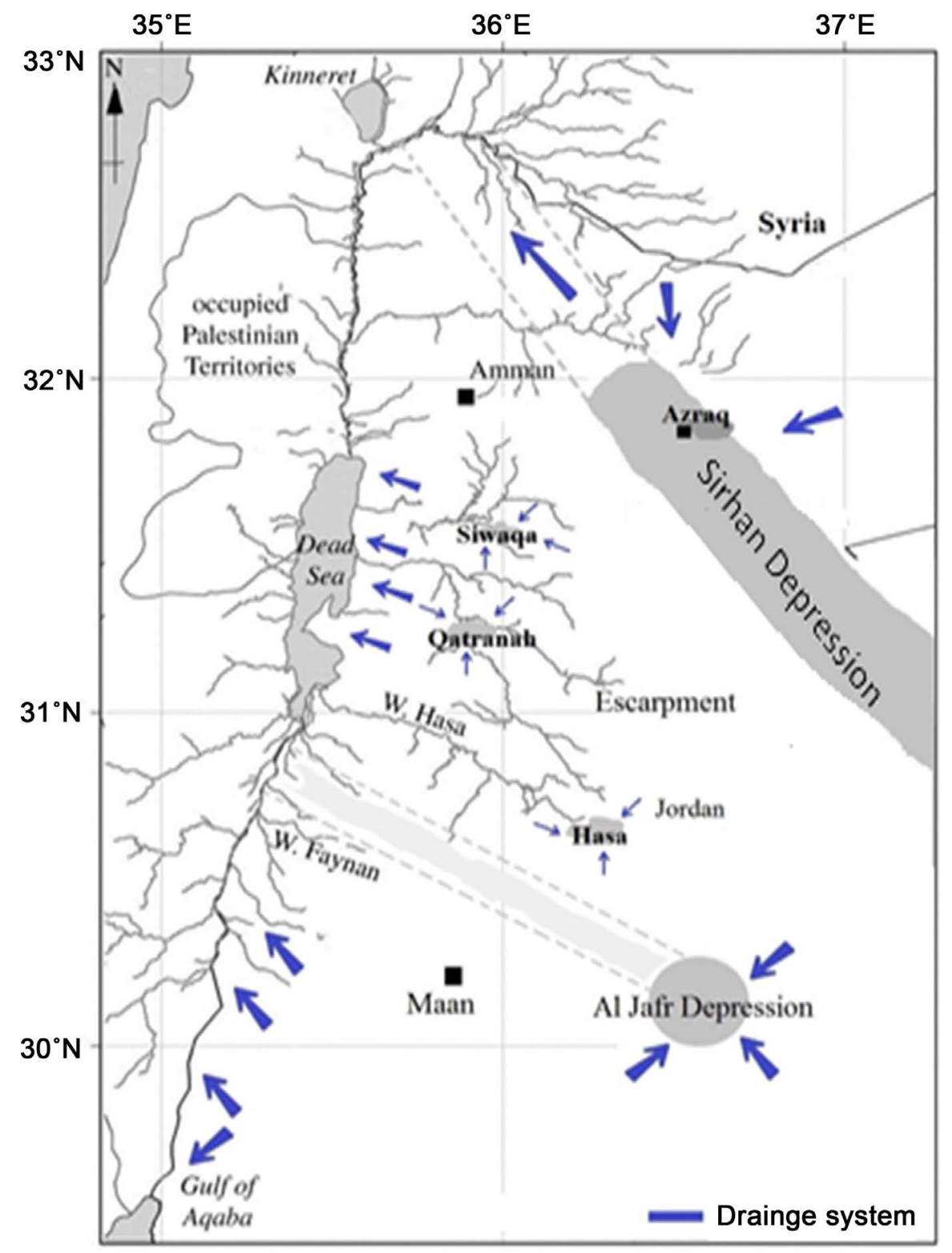

Figure 3. Surface water drainage accompanying the start of uplift along the JRV as a result of taphrogenic movements and the volcanic eruptions in Harrat es Sham and Sirhan Depression areas which led to the formation of Pleistocene lakes in Jafr, Hasa, Qatranah, Swaqa and other areas.

the Yarmouk to the eastern side of Tiberias Basin. At that time erosion of Jordanian lands produced gravel that was transported into the sinking Rift Graben as it can be well seen in the Qarn section as described by [12] and provided by pictures by [5]. A sea fauna was collected from the beaches at Waqqas also mentioned in [12] with pectin and sea urchins. Planktonic Foraminifera were determined from Al Qarn section and gave the age of Late Miocene to Early Oligocene [13].

During deposition of Tayba Formation, that is Late Oligocene to Early Miocene the sea had obviously flooded some parts of northern Jordan and the Jor- 
dan Dead Sea Rift begun to form, at the same time when Arabia began to rotate of Africa and the Red Sea Graben formed. The Sea flooded the northern part of the Rift, which has been sinking and had flanks with beaches between north of the Yarmouk to the eastern side of Tiberias Basin.

Volcanic eruptions of Huran and Harrat esh Sham (including Jabal Arab-Druz) started in Miocene [2] [14] and [15], and that coincided almost with the start of regression of the Tethys from the area. At that time or a little later the initiation of rifting along the JTF has started and later on the sinistral strike slip movement has begun.

The series of lakes which formed at the interface of the uplifted shoulders of the Jordan Valley and the westward sloping topography of East Jordan, such as Jafr, Hasa (Jinz), Qatraneh, Swaqa, Azraq etc. served as base levels for the surface and groundwater originating in the catchment areas extending from the eastern shoulders of the Rift Valley to the eastern escarpment overlooking wadi Sirhan (Table 1). Some of these lakes were afterwards captured by the nearby westwards-draining wadis into the Jordan Rift Valley such as Qatrana, Wala and Hasa (Figure 4).

The digital elevation model of the area (Figure 5) shows the present drainage system of the large basins of Sirhan, Hammad, Damascus and Tadmor (between Anti Lebanon and Palmyra mountain chains). This drainage is generally still oriented towards the area of Lake Tiberias and the Yarmouk River, at latitude $226^{\circ} \mathrm{N}-250^{\circ} \mathrm{N}$, Palestine Grid (PG). The basalts of Harrat esh Sham and Huran areas had built after their eruptions a hindering obstacle in the way of the surface water courses of the above mentioned drainage systems, which were during pre-basalt-eruption activities draining northwest towards the Jordan Valley area [7]. The surface water of the above mentioned drainage basins collects at present in areas at the interface of basaltic flows and the old pre-basalt topography forming water lakes, pools, oases and sabkhas, such as Azraq and Burqu in Jordan and Damascus and Hzouza in Syria [16] and [17].

Table 1. Pleistocene desert lakes in Jordan with proven human activities along their shores (implements).

\begin{tabular}{ccccc}
\hline Site of lake & Northing & Easting & Area $\left[\mathrm{km}^{2}\right]$ & Comments \\
\hline Azraq/Dahikiya & 314,907 & 365,353 & 600 & $\begin{array}{c}\text { In Pleistocene dried out totally in 1991, } \\
\text { beginning of Holocene } 220 \mathrm{~km}^{2}\end{array}$ \\
Jafr & 301,748 & 361,844 & 1800 & $\begin{array}{c}\text { Dried out at the end of the Pleistocene } \\
\text { Hasa }\end{array}$ \\
Qatrana & 304,674 & 360,337 & 30 & As above \\
Swaqa & 310,539 & 361,503 & 25 & As above \\
Safawi & 320,000 & 380,500 & 50 & $\begin{array}{c}\text { Still existing as mudflat filled with floodwater } \\
\text { in winter time and dry in summer time }\end{array}$ \\
Burqu' & 324,500 & 375,500 & 40 & As above \\
Unnamed & 323,300 & 380,000 & 40 & As above \\
\hline
\end{tabular}




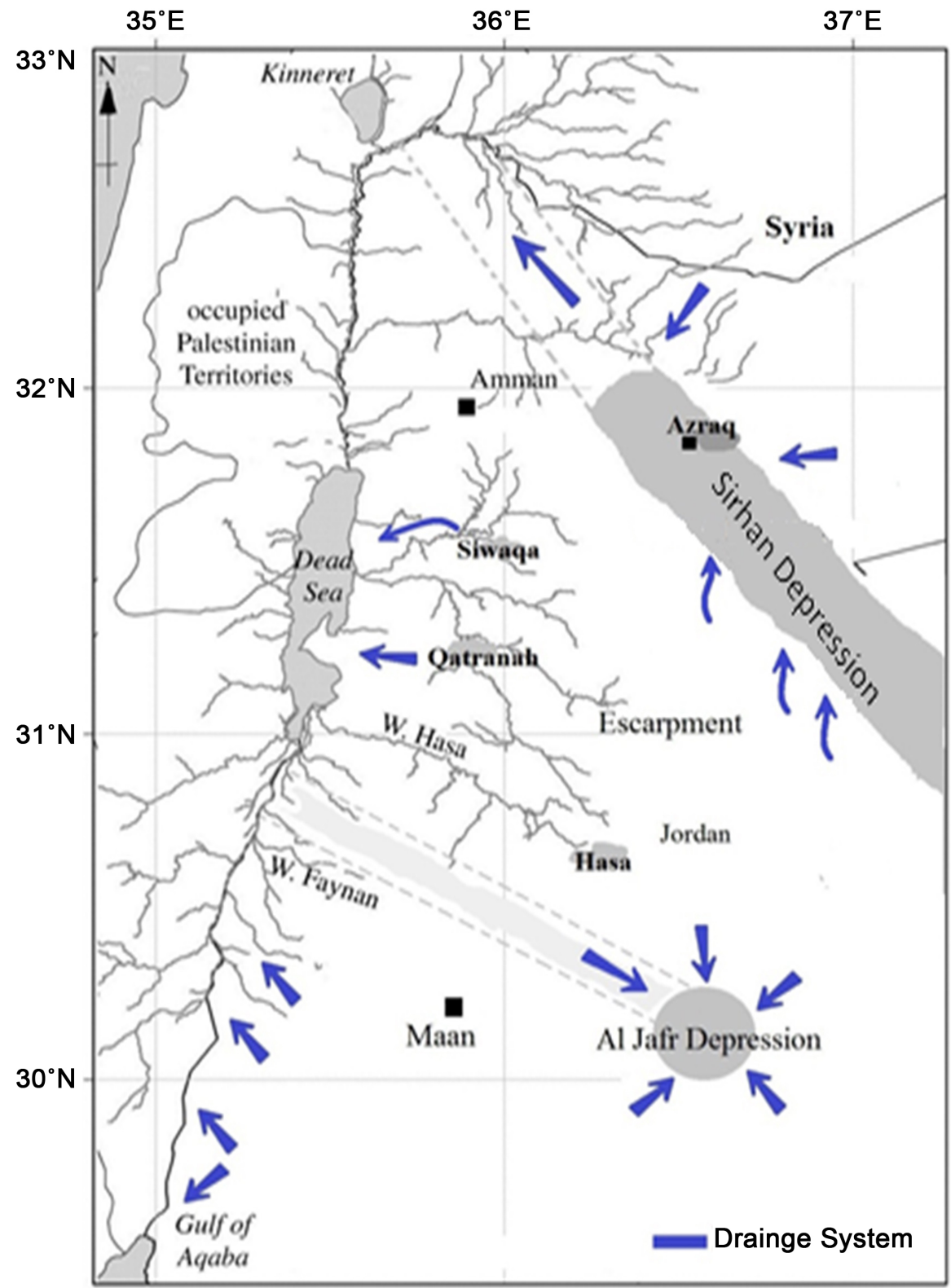

Figure 4. After the formation of the Pleistocene lakes (Figure 3) the strong head-ward erosion of wadis pouring into the JRV started advancing eastward and capturing the lakes' water of Hasa, Qatranah, and Swaqa by cutting into the eastern shoulders of the JRV. Higher erosion rates along wadis exceeding those of the uplift movements of the JRV eastern shoulders are the main reason of capturing the lakes water leading to the letter falling dry.

\subsection{Jafr and Azraq Depressions}

Jafr and Azraq depressions served from the start of the uplift of the shoulders of the Jordan Rift Valley as local base levels for surface and groundwater and, since that time, Jafr evolved from a permanent lake into a playa and Azraq into an oasis. The highlands surrounding these two depressions delivered their weathering products to the Tethys through the two depressions throughout the time from 


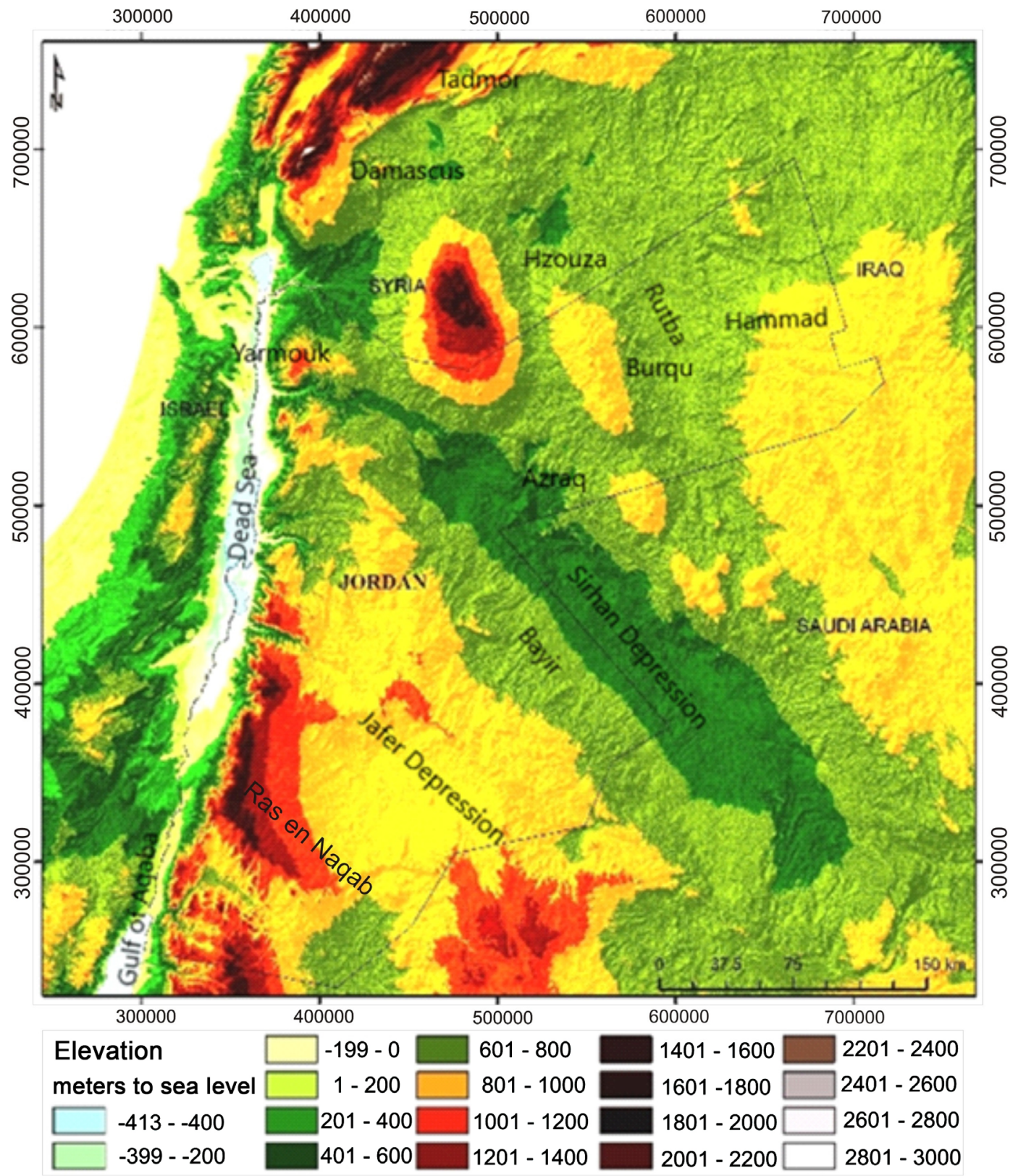

Figure 5. Digital elevation model (DEM) of Jordan and immediate surroundings showing the two main lows of Sirhan and Jafr depressions and the Jordan Rift Valley with the Dead Sea (The DEM was obtained from Satellite Data provided by the Royal Jordanian Geographic Center).

Lower Cretaceous onward whenever the Tethys regressed, until its last regression during Miocene when both depressions were cut off from reaching the Tethys (or afterwards the Mediterranean) by the formation of the Jordan Rift Valley. During the major transgressions of the Tethys; for instance during the Upper Cretaceous and Paleogene, these depressions served together with their surrounding highlands as sedimentation basins. The existence of the two depressions, Jafr and Sirhan, along with the corresponding elevated areas on their sides for such a long time, from Lower Cretaceous to the present, can only be explained by continuous relative uplift of the shoulders of these two depressions 
which are Ras en Naqb in the SW, Bayir in the middle and Rutba in the NE, compared to their bottoms. All these uplifts and depressions trend $\pm \mathrm{NW}-\mathrm{SE}$.

Figures 6(1)-(5) show the development of surface and groundwater flow patterns illustrated in the form of cross sections, from the start of the last retreat of the Tethys during Neogene until the present time. The Tethys started regressing and the area of Jordan was drained by two surface water systems namely; Sirhan and Jafr depressions striking SE-NW and draining NW towards the retreating Tethys [2], Jafr Lake was a fresh water lake occupying an area of around 1800 $\mathrm{km}^{2}$ [11] with fluviatile and lacustrine sediments of conglomerates, silt and carbonates containing Ostracoda, Heterocypris, Herpetocypris, Valvatataxa and others dating back to 26,000 years ago [3] [6] [11] and [18]. It dried out at the end of Pleistocene, forming a playa which collecting water only as a result of flood flows.

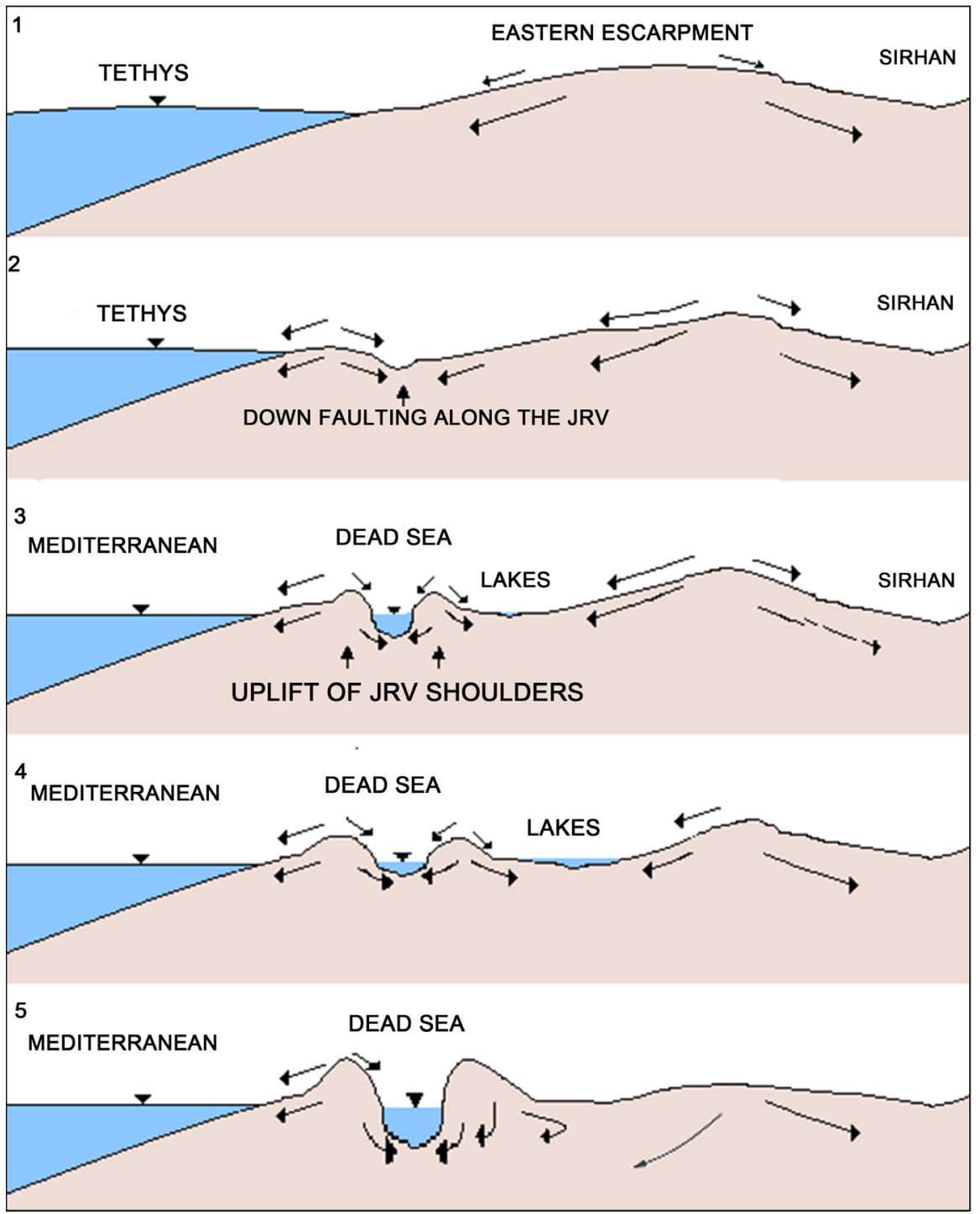

Figure 6. (1)-(5) Schematic hydrologic cross sections illustrating the development of the drainage system in Jordan after the start of the last regression of the Tethys during Neogene and the impacts of taphrogenic and epeirogenic movement on that system. 


\subsection{Hasa Lake}

This lake was a fresh water lake with an area of $18 \mathrm{~km}^{2}$, locally $4 \mathrm{~km}$ wide and its western edge at about $40 \mathrm{~km}$ from the escarpment of the JRV [18] [19] [20] [21] and [22]. It deposited gravel, marl and limestone containing Ostracods and Gastropods and cultural remains dating back to 26,000 - 19,000 years ago [23] and [24]. Hasa Lake dried out at the end of the Pleistocene period, because it was captured by Wadi Hasa head-ward erosion and discharges now into the Dead Sea.

\subsection{Swaqa Lake}

The lake water had been saline to hyper saline with travertine deposits containing reed roots and borrows [25] and [26]. The lake was captured by the head ward erosion of Wadi Wala, which joins Wadi Mujib that discharges into the Dead Sea.

\subsection{Hallat Ammar-Mudawara (Disi) Lake}

The lake water had been brackish with deposits of marl, dolomite, gypsum and halides containing Ostrapodes, Ostracoda, Hydrobia and Foraminifera dating back to 80.000 years ago [5] [9] [27] and [28]. This lake was captured by the head-ward erosion of Wadi Yutum which drains Disi area into the Gulf of Aqaba.

\subsection{Azraq 0asis}

Surface and groundwater which originated from what is now known as Hamad, Damascus and Azraq basins drained before the eruptions of Harrat ash Sham volcanic rocks through Sirhan depression into the retreating Tethys. After the start these eruptions the drainage system became gradually blocked by basalt rocks deposited along its water courses forming lakes and hindering the water from reaching the retreating Tethys. The basaltic rocks and the erosional products of the strong tectonic activity accompanying the taphrogenic and epeirogenic movements in the Levant area led to the formation of a variety of lakes along the ancient water courses at the interface of basalt and clastic masses on the one side with the older topography sloping towards the retreating Tethys in the NW on the other. One of the prominent examples of these lakes is Azraq Lake (Oasis) in Jordan, which until before three decades had a surface area of a few square kilometers and some $600 \mathrm{~km}^{2} 250 \mathrm{kyr}$ ago [8]. Azraq Lake started as a fresh water lake and turned gradually into a brackish and finally a salt water lake in which gravel, sand, marl, limestone and gypsum and halides were deposited.

Harrat esh Sham (Jabal Druz) basalts erupted in six phases [2] [14] and [15]. They started in Oligocene-Miocene with 4 phases, followed by the fifth phase lasting from Miocene to Pleistocene. The $6^{\text {th }}$ intensive phase of volcanic eruptions was the most extensive covering areas in the NE, E, SE, S, W and SW of Jabal Druz. It covered gravels of the $5^{\text {th }}$ phase in the area from the Yarmouk Riv- 
er to west Irbid. This 6th phase is of middle Pleistocene age and younger with the most recent eruption of 4000 - 4500 years ago (Bender, 1968, Van der Boom and Suwwan, 1966).

The sixth and last intensive volcanic eruption phase together with the taphrogenic and epeirogenic uplift movements and the resulting intensive erosion and mass movements are considered the causes of the final blocking of Sirhan drainage into the Jordan Valley area and hence the reason behind the shrinkage of Lisan Lake of about $3000 \mathrm{~km}^{2}$ to form the Dead Sea which existed until the $60 \mathrm{~s}$ of the last century of about $950 \mathrm{~km}^{2}$ [16]. For instance the Tuffa of the sixth phase measure $25 \mathrm{~m}$ in Dhuleil area and $25 \mathrm{~m}$ in Mafraq area. The base of the basalt along wadi Dhuleil slopes to the west to Zarqa River area and towards NW to the area just south of the Yarmouk River course [29], which strongly indicates the slope of drainage to the Jordan Rift Valley.

\subsection{Lisan Lake}

Lisan Lake; the ancestor sea of the present Dead Sea, occupied, until the end of the Pleistocene, an area along the Jordan Rift Valley of around $3000 \mathrm{~km}^{2}$ with a water level of $160-180 \mathrm{mbsl}$ [1] [2] and [30]. It gradually shrank to form the hyper saline Dead Sea with a surface area of $950 \mathrm{~km}^{2}$ and a water level of 395 mbsl during the 1950s and 1960s and to 430 mbsl in 2017 [31]. In the surroundings of Lisan Lake artifacts of different human cultures are found e.g. in Deir Alla at $\pm 180 \mathrm{mbsl}$, the entrance of Zarqa River into the JRF, in Thiraa at the entrance of wadi Karak into the JRV, in Sweima at the entrance of Wadi Hisban into the JRV and in wadi Zarqa Main at an elevation of \pm 180 mbsl [17] [32] [33] [34] and [35].

\section{Human Migration}

According to recent findings [36] the first humans, Homo erectus, migrating from Africa entered the Levant during the Early Pleistocene about 2 million years ago. Another wave of migration brought Heidelbergensis and Neanderthals at around $500 \mathrm{k}$ years to the Levant [37]. These humans came as hunters who followed predominantly large animals which represented their game. Along their way, they also collected roots, fruits and seeds from wild plants. They stayed near to locations with water and migrated between pastures as did the animals they hunted. The former presence of these early people is recognized especially at places of their rest, since they fabricated tools for hunting and for cutting their prey. In Jordan these tools were commonly made of flint. The shape of these tools changed with time, from relatively coarse implements of the more ancient hunters to instruments of finer fabric of later ones.

According to [37] [38] and others Homo sapiens arrived in the region around 70,000 to 50,000 years ago and replaced Neanderthal man. This change is not visible in the type of hunting tools. Schrenk [39] suggested that in the Mediterranean area Arabia was used by Homo erectus as migration route from Africa 
since 900,000 years. Azraq Basin and Lake and Al-Jafr Basin and lake and other lakes were nodes on a chain of ancient lakes that stretched from northwestern Saudi Arabia to northeastern Syria and held water during the wetter times of the Pleistocene. They formed an inland corridor for occupation by early men. These sites have yielded many heavy-duty butchering tools chipped from local deposits of flint. Around 600,000 years ago stone tools of the type of cleavers were in use and changed only little in shape until before around 100,000 years. The tools are cleavers which are a form of hand axes that could be sharpened again after use by striking distinctive flakes from the cutting edge.

Hand axes of lower Paleolithic style were found for example about $12 \mathrm{~km}$ to the east of Azraq in al-Dahikiya, where people periodically housed near the shore of a lake that existed here during pluvial times. Here they had their hunting station on a fan of sediment that had been washed from the east into the lake, and here they camped and produced their tools. These lake shores were also frequented by large animals ancestral to those that occupy the East African savannah today. The climate was relatively cool and dry with open steppe with grassland and scattered trees along the river beds.

Homo sapiens appeared in the region at least 50,000 years ago as has been recognized from human bones found in Levantine caves. North of Amman, along Zarqa River on older river terraces choppers were recognized with an assumed age of around 1 Million years, Early Acheulian [40]. Macumber [22] suggested that the choppers could also be around 200,000 years old. Also a similar place was found near the Metoritic impact locality of Waqf as Suwwan, near Wadi Sirhan, and has been interpreted as migrating route for humans from Africa to Eurasia [41].

During the Middle Pleistocene Homo erectus populations used the shores of Pleistocene Lake al Jafr for butchering large game animals, a lake reconstructed by [3]. The same kind of people has also camped in Azraq oasis at Ain Soda [1] [42], Ain el-Assad [43] [44]. The Hummalian period is dated to approximately 240,000 to 170,000 years ago. The Jordanian sites are factory sites, where blanks for tools were produced in considerable numbers, in the Jordan Valley (Zamliyah and near Munqiah). The Hummalian people regularly came to these areas to supply themselves with blanks for further use during their wanderings.

Ancient humans were also hunting along the shores of Lisan Lake [13]. Lisan Lake was salty and represented a distinct divide stretching from Lake Tiberias to the Wadi Araba south of the Dead Sea. On the margin of the Tabaqa plateau east and next to the Jordan Valley travertine formations hold detached blocks of travertine which have been transported to Lake Lisan from an original position upriver including old artifacts from the Levalloiso-Mousterian that lasted roughly from about 160,000 to about 45,000 years ago. Here flint blades are common, but difficult to recognize caused by trampling of grazing herds of sheep and goats. The hoofs of these animals destroy the edges of flint artifacts. The Yabrudian sites were from Tabaqa gravel fan that formed during the existence of Lake Li- 
san, these blocks are therefore part of the fan and transported from an original position upriver.

The ancient shores of Jafr Lake are littered with Levallois Mousterian and possible Upper Acheulian artifacts [9]. A period of progressive desiccation ensued, in which the lake became brackish, followed by a period when sheets of gravel spread over the Basin. Wind polished Levallois Mousterian artifacts were found on this surface.

Upper Paleolithic artifacts of Middle Paleolithic character occur on the surface of the playa of Azraq and also on the surface of a delta belonging to a moist phase. At about 350,000 to 325,000 years ago the Acheulean culture was replaced by the Yabrudian techno-complex a change in the tool set with more retouched flakes and fewer hand axes [45].

During the Upper Paleolithic and the subsequent Late Paleolithic Lake Lisan occupied the Jordan Valley at its highest levels, separating East Jordan from Palestine and partly Sinai in the area extending from Lake Tiberias to the Negev, creating a kind of dead end for settlements along its shores. This lake filled with salty water was of little interest to these hunters and gatherers, but its shores with so many fresh water rivers entering it became areas for hunting and settlement.

Paleolithic people were as hunters and gatherers constantly on the move. They generally occupied a site for several days or a few weeks at most. A place for camping might have been a clearing in the forest or the bush, an agreeable tree providing shade, or the proximity of a spring. A factor is also the availability of raw material. Some stone tools, such as hand axes or Levallois cores, are so diagnostic. During periods of increased rainfall or reduced evaporation during the colder periods of the Ice Age, a substantial body of water developed.

Animal hunted were for example the ostrich Struthio camelus, including its eggs and other birds, hartebeest (Alcelaphus), wild boar (Sus scropha), rhinoceros (Dicerorhinus hemitoechus), aurochs (Bos primigenius), equid (Equus), and elephants (Elephas hysudricus) [42]. The Acheulian site of Gesher is located 3.5 $\mathrm{km}$ south of the Hula Valley, bordered by the Golan Heights in the east and the Galilee mountains in the west. Skeletal animal remains found at the site reflect carcass processing of large and medium-sized animals, ranging from elephant Paleoloxodonta, large bovids and rhinoceros to gazelle, together with smaller animals like fishes and crabs. Fallow deer (Dama) bones are with cut marks. Fish processing (Cyprinidae carp, Barbus) and cabs were part of the diet of people at the site. Plant gathering is attested with the submerged species of prickly water lily Eurycale ferox and water chestnut Trapa natans and remains of species that grow near the lake, like acorns, wild grape Vitis sylvestris, olives, white beet Beta vulgaris and holy thistle Silybum marianum. They ate nuts and seeds. Mollusk coquinas represent beach and this facies association preserves the bulk of the stone tool, and fossil vertebrate remains.

Homo sapiens evolved in Africa in the late Middle Pleistocene [46]. When Li- 
san Lake filled with water, Homo sapiens could have been hunting near its shores. They have migrated across the Arabian Peninsula and migrations occurred in concert with a strengthened summer monsoon that led to the reactivation of lakes and rivers, as it did also in North Africa.

The Jordan Valley was occupied by Lake Lisan between 75,000 and 15,000 years ago, creating an important barrier to the movements of animals and humans. In Jordan, a blade industry relating to the Middle Paleolithic has been documented in the Azraq [42] and at the Ain Difla site [4]. A Middle Paleolithic assemblage in the largest spring of the south Azraq, called Ain Soda, has been documented in [47].

In the Jafr Basin $230 \mathrm{~km}$ SE of Amman a large lake had been in existence [3] resulting in the deposition of $25 \mathrm{~m}$ of limestone and marl-present below the mud flat of the Qa Jafr. Near the el Jafr Basin the area was supposedly covered by a large lake that deposited lacustrine limestone [19] [20]. But this Pleistocene Lake Hasa probably never existed [24] and these deposits are from swampy margins of Hasa River, and Mischke [6] also suggested a deposition in a wetland setting with shallow freshwater to slightly oligohaline ponds, streams, and swamps, based on the interpretation of ostracods. The presence of a large paleolake was based on the sedimentology and facies relationships, and the analysis of the microfauna was not supported. Root voids archaeological materials, and mammal fossils such as horse teeth suggest wetland setting in Wadi Hasa. Silt-matrix supported conglomerates were deposited during flooding events [24].

Lakes in the Sirhan depression that extends from Azraq far into Saudi Arabia may also have been present but had such a high salinity that Cardium of the bivalves and Ammonia of the foraminifera lived in it (Azraq Formation). At other periods it was filled in total or party by fresh water, also in sub-recent times, when fresh water gastropods such as Melanopsis and Melanoides lived here.

\section{Discussion and Conclusions}

Tectonic activities since at least Lower Cretaceous time created two main depressions in Jordan and its surrounding areas These depressions are Sirhan and Jafr trending NW-SE. With the onset of epeirogenic movements and regression of the Tethys during Neogene, these two depressions served as gulf areas and base levels for surface and groundwater and as sedimentation basins of clastic, chemical and biogenic rocks.

Continuous regression of the Tethys and the start of the formation of the JRV created a new base level for the surface and groundwater of the area and their sediment loads along the JRV.

The taphrogenic uplifts of the shoulders of the JRV gradually resulted in increasing elevations of these shoulders relative to the JRV bottom and to the areas lying east of theses shoulders. This created new base levels for water between the JRV eastern mountains and the eastern escarpment (Bayir Uplift) along the highlands Plateau of Jordan. The series of local base levels or lakes were oriented 
N-S parallel to the JRV and at distances of $40-60 \mathrm{~km}$ east of it. Such lakes are Jafr, Hasa, Qatranah, Swaqa and others (Figure 6).

Figure 6 illustrates the development of the highland lakes as follows:

- Figure 6(1): With the start of the last regression of the Tethys during Neogene an escarpment formed striking NNW-SSE forming a watershed between Sirhan depressions in the northeast and the retreating Tethys in the west.

- Figure 6(2): Down-faulting along the Jordan Rift Valley (JRV) had changed the surface and groundwater base levels and directed them to the newly developing JRV.

- Figure 6(3): Uplift of the JRV shoulders and the formation of lakes between the escarpment in the east and the eastern shoulder of the JRV in the west also resulted in the following base levels for surface and groundwater; namely, the Mediterranean in the west, the Dead Sea in the middle and Sirhan depression in the east, in addition to the local lakes such as Jafr, Hasa Swaqa and Qatranah.

- Figure 6(4): Further uplift of the JRV shoulders and shift of lake sites further east: Groundwater in the aquifers of the rising eastern shoulder of the JRV leaked upward and discharged into the lakes formed between the eastern escarpment and the eastern shoulder mountains of the JRV.

- Figure 6(5): Lakes, such as Qatranah, Swaqa, Jinz (Hasa) became captured by wadis draining into the JRV or into Sirhan depression by head ward erosion, which caused gradual drying of the lakes. The recharged water of the area between the eastern shoulder of the JRV and the eastern escarpment started, after flowing short distance in an easterly direction to infiltrate deeper and reach the deep sandstone aquifer complex and to flow in a westerly direction towards the deepening JRV.

On the other hand Sirhan depression, which drained in a NW direction was gradually blocked by the volcanic eruptions of Harrat ash Sham basalts, lava flows and intensive clastic sedimentation reaching it as a result of strong taphrogenic uplifts and hence erosion along its catchment area. This blocking created local lakes at the interface of basalt flows and the pre-eruption topographic slopes. Such a lake is still present in Azraq (Azraq Oasis) and many others collect only flood water still to be found in Jordan, Syria and Saudi Arabia at the peripheries of Harrat Ash Sham basalts.

All above mentioned lakes collected at their beginnings fresh water and clastic sediments were deposited as can be indicated by their sediments and fossil contents of fresh water. Among the gastropods fossils Melanopsis sp., Theodoxus sp., Bithynia sp., Pupilla sp., Bulimus sp., Gyraulus ehrenbergi, Galba truncatula, Melanoides tuberculata, Ancylus sp., Valvata sp., and Lymnaea sp., indicate fresh water environment [3] [7] [23] and [26]. Fossil fresh water bivalve are also reposted such as Pisidium sp. and Unio sp. [26].

Ostracods assemblages found in the aquatic sediments with fresh water to slightly salty water conditions, including Ilyocypris cf. bradyi, Cypridopsis vidu, 
Cypris pubera, Herpetocypris brevicaudata, Candona neglecta, Heterocypris salina, Pseudocandona sp. and Fabaeformiscandona fabaeformis [6].

Humans, since a few hundred thousand years dwelled at the shores of such lakes that served as these humans survival sources of food and water as indicated by the implements found at the ancient shores of the lakes.

Many of these lakes such Jafr, Hasa, Qatranah and Swaqa fell dry due to drier climate and their capturing by head ward erosion of wadis draining into the JRV such as Hasa, Mujib and Wala.

It seems that the migration waves of humans; Homo erectus (around 2 million years ago), the Neanderthal (around $500 \mathrm{kyr}$ ago) and Homo sapiens (around 50 - 70 kyr ago) from Africa to east Jordan and from there further east and north were not possible without the presence of these lakes which served as a source of water and food (hunting and fishing) and where humans found shelters.

\section{Conflicts of Interest}

The authors declare no conflicts of interest regarding the publication of this paper.

\section{References}

[1] Burdon, D.J. and Quennell, A.M. (1959) Handbook of the Geology of Jordan: To Accompany and Explain the three sheets of the 1:250,000 Geological Map of Jordan East of the Rift by Albert M. Quennell. Government of the Hashemite Kingdom of Jordan, Amman.

[2] Bender, F. (1968) Geologie von Jordanien-Beitraege zur regionalen Geologie der Erde. Gebrüder Bornträger, Berlin.

[3] Huchriede, R. and Wiesemann, G. (1968) Der junpleistozne pluvial von El-Jafr und wietere daten zum Quartaer Jordanieas. Geologica Palaeontologica, 2, 73-90.

[4] Clark, I., Khoury, H., Salameh, E., Fritz, P., Goksu, Y., Wieser, A. and Fontes, J. (1992) Travertines in Central Jordan. IAEA-SM-319/6, 551-565.

[5] Bandel, K. and Salameh, E. (2013) Geologic Development of Jordan-Evolution of Its Rocks and Life. Deposit No. 690/3/2013 of the National Library, Amman, 278 p.

[6] Mischke, S., Opitz, S., Kalbe, J., Ginat, H. and Al-Saqarat, B. (2015) Palaeoenvironmental Inferences from Late Quaternary Sediments of the Al Jafr Basin, Jordan. Quaternary International, 382, 154-167. https://doi.org/10.1016/j.quaint.2014.12.041

[7] Mischke, S., Ginat, H., AlSaqarat, B.S., Faerstein, G., Porat, N. and Rech, J. (2017) Fossil-Based Reconstructions of Ancient Water Bodies in the Levantine Deserts. In: Enzel, Y. and Bar-Yosef, O., Eds., Quaternary Environments and Humans in the Levant, Cambridge University Press, Cambridge, 381-389. https://doi.org/10.1017/9781316106754.045

[8] Davies, C.P. (2005) Quaternary Paleoenvironments and Potential for Human Exploitation of the Jordan Plateau Desert Interior. Geoarchaeology, 20, 379-400. https://doi.org/10.1002/gea.20055

[9] Rech, J.A., Ginat, H., Catlett, G.A., Mischke, S., Winer Tully, E. and Pigati, J.S. (2017) Pleistocene Water Bodies and Associated Geologic Deposits in the Southern Levant. In: Enzel, Y., Bar-Yosef, O., Eds., Quaternary Environments and Humans in 
the Levant, Cambridge University Press, Cambridge. https://doi.org/10.1017/9781316106754.014

[10] Quennell, A.M. (1958) The Structural and Geomorphic Evolution of the Dead Sea Rift. Quarterly Journal of the Geological Society, 114, 1-24. https://doi.org/10.1144/gsigs.114.1.0001

[11] Quintero, L.A. and Wilke, P.J. (1998) Archaeological Reconnaissance in the al-Jafr Basin, 1997. Annual of the Department of Antiquities of Jordan, 42, 113-121.

[12] Bandel, K. and Shinaq, R. (2003) The Sea in the Jordan Rift (Nordern Jordan) during Oligocene/Miocene Transition with Implications to the Reconstruction of the Geological History of the Region. Paläontologie, Stratigraphie, Fazies, 11, 97-115.

[13] Bandel, K., Alhejoj, I. and Salameh E. (2016) Geologic evolution of the Tertiary-Quaternary Jordan Valley with Introduction of the Bakura Formation. Freiberger Forschungshefte, 23, 103-135.

[14] Van Den Boom, G. and Sawwan, O. (1966) Report on Geological and Petrological Studies of the Plateau Basalts in NE-Jordan. Unpublished Report German Geologic Mission in Jordan, Amman.

[15] Ibrahim, K.M., Shaw, J., Baker, J., Khoury, H., Rabba, I. and Tarawneh, K. (2006) Pliocene-Pleistocene Volcanism in Northwestern Arabian Plate (Jordan): I. Geology and Geochemistry of the Asfar Volcanic Group. Neues Jahrbuch für Geologie und Paläontologie-Abhandlungen, 242, 145-170. https://doi.org/10.1127/njgpa/242/2006/145

[16] Salameh, E. and Al Farajat, M. (2007) The Role of Volcanic Eruptions in Blocking the Drainage Leading to the Dead Sea Formation. Environmental Geology, 52, 519-527. https://doi.org/10.1007/s00254-006-0484-x

[17] Wolfart, R. (1967) Geologie von Syrien and Libanon-Beiträge zur regionalen Geologie der Erde. Gebrüder Bornträger, Berlin.

[18] Ginat, H., Opitz, S., Ababneh, L., Faershtein, G., Lazar, M., Porat, N. and Mischke, S. (2017) Pliocene-Pleistocene Water Bodies and Associated Deposits in Southern Israel and Southern Jordan. Journal of Arid Environments, 148, 14-33.

[19] Schuldenrein, J. and Clark, G.A. (1994) Landscape and Prehistoric Chronology of West-Central Jordan. Geoarchaeology, 9, 31-55. https://doi.org/10.1002/gea.3340090103

[20] Schuldenrein, J. and Clark, G.A. (2003) Prehistoric Landscapes and Settlement Geography along the Wadi Hasa, West-Central Jordan. Part I: Geoarchaeology, Human Palaeoecology and Ethnographic Modelling. Environmental Archaeology, 6, 23-38.

[21] Davies, C. (2007) Past Environments of the Jordan Plateau from the Paleolakes of the Eastern Desert. Crossing Jordan: North American Contributions to the Archaeology of Jordan, 79-86.

[22] Macumber, P. (2008) Evolving Landscape and Environment in Jordan. Equinox Publishing, 7-34.

[23] Moumani, K., Alexander, J. and Bateman, M.D. (2003) Sedimentology of the Late Quaternary Wadi Hasa Marl Formation of Central Jordan: A Record of Climate Variability. Palaeogeography, Palaeoclimatology, Palaeoecology, 191, 221-242. https://doi.org/10.1016/S0031-0182(02)00715-0

[24] Winer, E.R. (2010) Interpretation and Climatic Significance of Late Quaternary Valley-Fill Deposits in Wadi Hasa. West-Central Jordan. Unpublished M.Sc. Thesis, Department of Geology, Miami University, Miami, 97. 
[25] Khoury, H.N. and Abu-Jayyab, A. (1995) Research Note to the Mineral Volkonskoite; Four New Localites in Central Jordan. Dirasat, 22, 189-198.

[26] Alhejoj, I. and Bandel, K. (2013) Mollusks of the Pleistocene Al-Qarn Formation of the Jordan Rift-Valley in Jordan. Freiberger Forschungshefte, C, 545, 141-173.

[27] Masri, A. (1988) The Geology of Halat Ammar and Al Mudawwara, Map Sheet Nos. Natural Resources Authority, Geological Mapping Directorate, Geological Mapping Division, Amman.

[28] Petit-Maire, N., Carbonel, P., Reyss, J.L., Sanlaville, P., Abed, A., Bourrouilh, R. and Yasin, S. (2010) A Vast Eemian Palaeolake in Southern Jordan $\left(29^{\circ} \mathrm{N}\right)$. Global and Planetary Change, 72, 368-373. https://doi.org/10.1016/j.gloplacha.2010.01.012

[29] MacDonald, M. and Humanity Technical Services Limited (1966) Wadi Dhuleil Irrigation Project-Hydrogeology. Central Water Authority, Jordan, Amman, London.

[30] Neev, D. and Emery, K.O. (1967) The Dead Sea: Depositional Processes and Environments of Evaporates. Israel Geological Survey Bulletin, 41, 147 p.

[31] Potash Company Jordan. Open Files 2018.

[32] Bookman, R., Bartov, Y., Enzel, Y. and Stein, M. (2006) Quaternary Lake Levels in the Dead Sea Basin: Two Centuries of Research.

[33] Bartov, Y., Stein, M., Enzel, Y., Amotz-Agnon, A. and Ze'ev Reches, Z. (2002) Lake Levels and Sequence Stratigraphy of Lake Lisan, the Late Pleistocene Precursor of the Dead Sea. Quaternary Research, 57, 9-21. https://doi.org/10.1006/qres.2001.2284

[34] Agnon, A. and Goring-Morris, N. (2014) Settlement on the Shores of Lake Lisan and Adjacent Swamps: Hindered Aridization. American Geophysical Union, 33D-1278.

[35] Maher, L., Macdonald, D.A., Alaica, A., Banning, E.D., Jay, T. and Stock, J.T. (2014) Two Early Epipalaeolithic Sites in Wadi Taiyiba, Northern Jordan. Paléorient, 40, 73-97. https://doi.org/10.3406/paleo.2014.5617

[36] Garcia, T., Féraud, G., Falguères, C., de Lumley, H., Perrenoud, C. and Lordkipanidze, D. (2010) Earliest Human Remains in Eurasia: New 40Ar/39Ar Dating of the Dmanisi Hominid-Bearing Levels, Georgia. Quaternary Geochronology, 5, 443-451. https://doi.org/10.1016/j.quageo.2009.09.012

[37] Lopez, S.D. and Hallenthal, G. (2016) Human Dispersal Out of Africa. A Lasting Debate. Evolutionary Bioinformatics Online, 11, 57-68. https://doi.org/10.4137/EBO.S33489

[38] Washburn, S.L. (1960) Tools and Human Evolution. Scientific American, 203, 62-75. https://doi.org/10.1038/scientificamerican0960-62

[39] Schrenk, F., Bromage, T.G., Betzler, C.G., Ring, U. and Juwayeyi, Y.M. (1993) Oldest Homo and Pliocene Biogeography of the Malawi Rift. Nature, 365, 833-836. https://doi.org/10.1038/365833a0

[40] Besançon, J., Copeland, L., Hours, F., Macaire, J. and Sanlaville, P. (1984) The Lower and Middle Paleolithic in the Upper Zarqa-Khirbet Samra Area of Northern Jordan: 1982-1983 Survey Results. Annual of the Department of Antiquities, 28, 91-141.

[41] Olszewski, D.I. (2000) The Epipaleolithic in the Wadi Al-Hasa: An Overview. Archaeological Excavations in the Wadi Hasa, 2, 227-243.

[42] Rollefson, G., Schnurrenberger, D., Quintero, L., Watson, R.P. and Low, R. (1997) Ain Soda and 'Ayn Qasiya: New Late Pleistocene and Early Holocene Sites in the 
Azraq Shishan Area, Eastern Jordan. In: Gebel, H.G.K., Kafafi, Z. and Rollefson, G.O., Eds., The Prehistory of Jordan, II: Perspectives from 1997 Studies in Early Near Eastern Production, Subsistence and Environment 4, Ex Oriente, Berlin, 45-58.

[43] Rollefson, G.O. (1983) Two Seasons of Excavations at 'Ain el-Assad near Azraq, Eastern Jordan, 1980-1981. Bulletin of the American Schools of Oriental Research, 252, 25-34. https://doi.org/10.2307/1356835

[44] Copeland, L., Hours, F. and Series, B.I. (1989) Two Late Quaternary Pollen Profiles from Ain El-Assad, Azraq, Jordan. The Hammer on the Rock: Studies in the Early Paleolithic of Azraq, Jordan, 1, 259.

[45] Jagher, R. (2016) Nadaouiyeh Aïn Askar, an Example of Upper Acheulean Variability in the Levant. Quaternary International, 411, 44-58.

https://doi.org/10.1016/j.quaint.2016.02.006

[46] Clark, J.D., Beyene, Y., WoldeGabriel, G., Hart, W.K., Renne, P.R., Gilbert, H., Boisserie, J.R., et al. (2003) Stratigraphic, Chronological and Behavioural Contexts of Pleistocene Homo Sapiens from Middle Awash, Ethiopia. Nature, 423, 747. https://doi.org/10.1038/nature01670

[47] Rollefson, G.O., Quintero, L.A. and Wilke, P.J. (2006) Late Acheulian Variability in the Southern Levant: A Contrast of the Western and Eastern Margins of the Levantine Corridor. Near Eastern Archaeology, 69, 61. 